\title{
The Influence of Teacher's Language Politeness in Improving Student's Academic Motivation
}

\author{
Mantasiah \\ Germany Education \\ Faculty of Languages and Literature \\ Universitas Negeri Makassar \\ Makassar, Indonesia
}

\author{
Yusri \\ Germany Education \\ Faculty of Languages and Literature \\ Universitas Negeri Makassar \\ Makassar, Indonesia
}

\begin{abstract}
-this study aimed to determine the influence of teacher's language politeness in improving students' academic motivation. This research used experiment approach. To measure the motivation of students, the researcher adopted the Achievement Motivation Scale (AMS). The results showed that the academic motivation of experimental group was higher than the control group. It has proven that the teacher's language politeness has a pivotal role in improving students' academic motivation.
\end{abstract}

Keywords-academic motivation; speech act; language politeness; AMS scale

\section{INTRODUCTION}

Research topic about student's academic motivation is very essential to be conducted. Academic motivation has a vital role in learning process such as to determine what things that can be used to improve learning, to clarify the studying objectives that want to be attained, to determine the various obstacles toward the stimulation to study, to determine the perseverance in studying. [1]. Some studies found the significant correlation between learning strategies and student's academic motivation [2], [3]. Therefore, to improve students' academic motivation, it needs to find out the quick learning method or strategy that can be used in the learning process.

Several triggers can affect the students' academic motivation like learning facility, supporting from family, and others. Based on the result of the observation conducted by the researcher, it shows that one of the reasons that can influence student's academic motivation comes from teachers or educators. The way how a teacher utters to the students tends to affect the student's academic motivation. The result of the interview shows that students prefer to teach the teachers that often give the appreciation, sympathy, and other polite utterances. These can improve the students' pleasure to study that can affect the student's academic motivation.

This study focused on knowing that whether the linguistic politeness of a teacher has a significant impact on the student's academic motivation. The results of this research will be helpful in the education world. This also can be made as one of the strategies of the teachers to improve the student's academic motivation.

Research regarding linguistic politeness has been done by the previous researchers like [4]-[6] and other influential researchers. Nevertheless, some of those researchers emphasize the concept of linguistic politeness as the conflict strategy. In this research, the researcher does not explain how the politeness concept is made as the conflict strategy, but the researcher explains how the language politeness of teacher influences students' academic motivation.

\section{POLITENESS THEORY}

The concept of linguistic politeness must be understood to avoid the conflicts. The understanding regarding this case later can be functioned to control the potential of threatening like in face-threatening acts. [7]. The correlation between politeness and good communication. Communication will flow smoothly when a speaker and a hearer understands the concept of politeness [8]. Some studies explain regarding the politeness in speech case. Linguistic politeness has been conceptualized as one of conflict strategy in social interaction. [9], [10]. This statement is what has been stated by Leech and Goffman.

Maxims that universally are followed to show the linguistic politeness [11]. These maxims are used as the benchmark that is used by the teachers in experiment class. These maxims are also used as a standard to make an observation guideline in the learning process. These are the maxims explained before:

1) The tact maxim: the concept of tact maxim is minimizing cost to other and maximizing cost to other. When the speaker talks and violates this concept, this make the utterance that the speaker made is impolite. Then, the utterance is concluded as an impolite utterance, especially in the aspect of tact.

2) The Generosity Maxim: the concept of generosity maxim is minimizing benefit to self and maximizing cost to self. When the utterance is violating this concept of this generosity maxim, it means that the utterance stated by the speaker is impolite especially in the aspect of generosity. 
3) The Approbation Maxim: the concept of the approbation maxim requires to minimizing dispraise of other and maximizing praise of other. When the utterance made by the speaker does not follow this maxim, it means the utterance is impolite especially in the aspect of approbation.

4) The Modesty Maxim: the concept of the modesty maxim is the participants must minimize praise of self and maximize dispraise of self. When the utterance breaks or violates this maxim, it means the utterance made by the participants is impolite especially in the aspect of modesty.

5) The Agreement Maxim: the concept of the agreement maxims shows that there is a tendency to maximize agreement between self and other people and minimize the agreement between self and other. When the utterance violates or breaks this concept, it means that the utterance is impolite especially in the aspect of the agreement.

6) The Sympathy Maxim: the concept of the sympathy maxim explains to minimize the antipathy between self and other and maximize sympathy between self and other. When the utterance violates or breaks this concept, it means the utterance is impolite especially in the aspect of sympathy.

The maxims including in linguistic politeness and divide it into the tact maxim, the agreement maxim, the generosity maxim, the approbation maxim, the agreement maxim, and the sympathy maxim. The concept of maxims written by Wijana in his book has no difference with the concept of linguistic politeness that has been explained above. Overall, the concept that they proposed refers to the theory of linguistic politeness that every person has the notions of "face," and every person realizes that the other people also have "face." So, when the people interact and communicate each other, they must maintain and cooperate to respect their "face."[12]

\section{RESEARCH METHOD}

The type of this study is quantitative research using experiment approach. This research was conducted at one of the elementary schools in Makassar. The Participants of this study are elementary school students in the 6th grade that consists of 2 classes. Those classes are divided into the control class and experiment class, and each class has 25 students. Data collection technique used in this research consists of an interview, observation, and scale. The researcher prefers to adopt the Achievement Motivation Scale (AMS) to measure the academic motivation of students. AMS is an instrument to measure Self Determination Theory. This theory identifies three levels of academic motivation-intrinsic, extrinsic, and motivation.

The instrument has been tested and accepted as being a reliable test of motivation in students and has been used reliably to study and measure motivation levels in elementary, high school, and undergraduate university students, in some different languages [13]. Also, the validation of the scale has enjoyed in a variety of studies [14], [15]. Qualitative data that have been collected through interview and observation is analyzed using the descriptive qualitative method, and the quantitative data like the data of student's academic motivation is analyzed statistically like statistic descriptive, independent sample t-test and paired sample t-test.

\section{DISCUSSION}

The first phase that was conducted before identifying the level of student's academic motivation is identifying the hypothetic mean value and hypothetic deviation standard. From the result of the measurement, the hypothetic mean value is 45 while the hypothetic deviation standard is 12,5 . Continuously, the average value of the students' academic motivation of experiment group and control group both pretest and posttest is shown here. For the details, it can be observed from the table below:

TABLE I. STUDENT'S ACADEMIC MOTIVATION

\begin{tabular}{|c|c|c|c|c|c|}
\hline \multirow{3}{*}{ Academic Motivation } & \multirow{3}{*}{ Categorization } & \multicolumn{4}{|c|}{ Frequency } \\
\hline & & \multicolumn{2}{|c|}{ Control Group } & \multicolumn{2}{|c|}{ Experiment Group } \\
\hline & & Pre-test & Post-test & Pre-test & Post-test \\
\hline$X \leq 26.25$ & Very Low & 0 & 0 & 0 & 0 \\
\hline $26.25<X \leq 38.75$ & Low & 4 & 3 & 4 & 0 \\
\hline $38.75<X \leq 51.25$ & Moderate & 21 & 22 & 21 & 1 \\
\hline $51.25<X \leq 63.75$ & High & 0 & 0 & 0 & 23 \\
\hline$X>63.75$ & Very High & 0 & 0 & 0 & 1 \\
\hline Mean & & 42.28 & 43.16 & 42.92 & 59.8 \\
\hline Deviation Standard & & 4.01 & 4.14 & 6.19 & 2.79 \\
\hline Category & & Low & Moderate & Moderate & High \\
\hline
\end{tabular}

TABLE II. PAIRED SAMPLES T-TEST OF CONTROL GROUP

\begin{tabular}{|c|c|c|c|c|c|c|c|c|c|}
\hline \multirow{4}{*}{ Pair 1} & \multirow{4}{*}{$\begin{array}{l}\text { PostTest- } \\
\text { Pre Test }\end{array}$} & \multicolumn{5}{|c|}{ Paired Differences } & \multirow{3}{*}{$\begin{array}{r}\mathbf{t} \\
1.780\end{array}$} & \multirow{3}{*}{$\begin{array}{r}\mathbf{d f} \\
24\end{array}$} & \multirow{3}{*}{$\begin{array}{l}\begin{array}{l}\text { Sig (2- } \\
\text { tailed) }\end{array} \\
.088\end{array}$} \\
\hline & & \multirow[t]{2}{*}{ Mean } & \multirow[t]{2}{*}{$\begin{array}{c}\text { Std. } \\
\text { Deviation }\end{array}$} & \multirow{2}{*}{$\begin{array}{c}\text { Std. } \\
\text { Error } \\
\text { Mean }\end{array}$} & \multicolumn{2}{|c|}{$\begin{array}{l}\text { 95\% Confidence Interval of the } \\
\text { Difference }\end{array}$} & & & \\
\hline & & & & & Lower & Upper & & & \\
\hline & & .880 & 2.472 & .494 & -.140 & 1.900 & & & \\
\hline
\end{tabular}


TABLE III. PAIRED SAMPLES T-TEST OF EXPERIMENT GROUP

\begin{tabular}{|c|c|c|c|c|c|c|c|c|c|}
\hline & & \multicolumn{5}{|c|}{ Paired Differences } & $\mathbf{t}$ & Df & Sig (2- \\
\hline \multirow[t]{3}{*}{ Pair 1} & \multirow[t]{3}{*}{$\begin{array}{l}\text { PostTest- } \\
\text { PreTest }\end{array}$} & \multirow[t]{2}{*}{ Mean } & \multirow[t]{2}{*}{$\begin{array}{c}\text { Std. } \\
\text { Deviation }\end{array}$} & \multirow{2}{*}{$\begin{array}{c}\text { Std. } \\
\text { Error } \\
\text { Mean }\end{array}$} & \multicolumn{2}{|c|}{$\begin{array}{l}\text { 95\% Confidence Interval of the } \\
\text { Difference }\end{array}$} & \multirow{3}{*}{17.130} & \multirow{3}{*}{24} & \multirow{3}{*}{.000} \\
\hline & & & & & Lower & Upper & & & \\
\hline & & 16.880 & 4.927 & 0.985 & 14.846 & 18.914 & & & \\
\hline
\end{tabular}

TABLE IV. INDEPENDENT SAMPLES TEST OF POSTE-TEST RESUlt (CONTROL AND EXPERIMENT GROUP)

\begin{tabular}{|c|c|c|c|c|c|c|c|c|c|c|}
\hline & \multirow{2}{*}{\multicolumn{2}{|c|}{$\begin{array}{l}\text { Levene's Test for } \\
\text { Equality of } \\
\text { Variances }\end{array}$}} & \multicolumn{7}{|c|}{ T-test for Equality of Means } \\
\hline & & & & \multirow[t]{2}{*}{$T$} & \multirow[t]{2}{*}{$D f$} & \multirow{2}{*}{$\begin{array}{l}\text { Sig. }(2- \\
\text { tailed })\end{array}$} & \multirow{2}{*}{$\begin{array}{c}\text { Mean } \\
\text { Difference }\end{array}$} & \multirow{2}{*}{$\begin{array}{l}\text { Std. Error } \\
\text { Difference }\end{array}$} & \multicolumn{2}{|c|}{$\begin{array}{l}95 \% \text { Confidence Interval of the } \\
\text { Difference }\end{array}$} \\
\hline & & $F$ & Sig. & & & & & & Lower & Upper \\
\hline \multirow{2}{*}{$\begin{array}{l}\text { Post } \\
\text { Test }\end{array}$} & $\begin{array}{c}\text { Equal } \\
\text { variances } \\
\text { assumed }\end{array}$ & 1.677 & .202 & 16.53 & 48 & .000 & 16.640 & 1.006 & 14.617 & 18.663 \\
\hline & $\begin{array}{c}\text { Equal } \\
\text { variances not } \\
\text { assumed }\end{array}$ & & & 16.53 & 41.918 & .000 & 16.640 & 1.006 & 14.609 & 18.671 \\
\hline
\end{tabular}

Table 1 shows that there is a comparison between the control group and experiment group both pretest value and posttest value. Based on the data shown, it can be concluded that there is a significant improvement of the student's academic motivation in the experiment group. Moreover, table 2 and 3 shows paired sample test result between pretest and posttest in experiment group and control group. The experiment group has sig value 0,00 which is smaller than 0,05 . Therefore, it can be concluded that there is a significant difference between pretest and posttest value of experiment group. The reverse trend is shown by control group which has sig value 0,088 . The sig value is more than 0,05 ; it can be concluded that there is no a significant difference between pretest and posttest value of control group.

Table 4 describes the result of independent sample t-test. Based on the table, it can be concluded that sig value is 0.00 . The value is lower than 0.005 proves that there is a significant difference of the posttest result shown by control group and experiment group. Based on the data, it showed that the experiment group or the group where the teacher used polite language which is based on the theory of linguistic politeness has academic motivation higher than the control group. Therefore, it can be seen that the language politeness of the teachers has a role in improving the student's academic motivation.

The result of this research shows that linguistic politeness does not only have a role as one of the strategies to overcome the conflict like that has been researched. [4]-[6]. Nevertheless, in this case, linguistic politeness also has a role in educational, primarily to improve the student's academic motivation. Based on the result after interviewing the students, it can be concluded that the utterances of the teachers that follow the theory of language politeness can improve the academic motivation of students in the learning process.

\section{CONCLUSION}

Through the discussion and result of the research that has been explained previously, it can be concluded that there is a difference of academic motivation of experience group and control group. When the teachers use the utterances that follow the language politeness theory, the students have higher academic motivation. In this case, it can be seen that one of the factors that can impact the student's academic motivation is caused by the how the teachers express their utterances to the students in learning process.

\section{References}

[1] A. Romadloni and R. Mantasiah, "Intercultural approach in foreign language learning to improve students' motivation," Sr. Ed., p. 61.

[2] R. Oxford and M. Nyikos, "Variables affecting choice of language learning strategies by university students," Mod. Lang. J., vol. 73, no. 3, pp. 291-300, 1989.

[3] M. Ehrman, "The role of personality type in adult language learning: An ongoing investigation," Lang. Aptit. reconsidered, pp. 126-178, 1990.

[4] F. Bargiela-Chiappini, "Face and politeness: new (insights) for old (concepts)," J. Pragmat., vol. 35, no. 10, pp. 1453-1469, 2003.

[5] C. Garcia, "Apologizing in English: Politeness strategies used by native and non-native speakers," Multilingua-Journal Cross-Cultural Interlang. Commun., vol. 8, no. 1, pp. 3-20, 1989.

[6] T. S. T. I. Suzila and M. N. M. Yusri, "Politeness: Adolescents in Disagreements," Int. J. Soc. Sci. Humanit., vol. 2, no. 2, p. 127, 2012.

[7] B. Ambuyo, F. Indede, and P. Karanja, "Face threatening acts and standing Orders:'politeness' or 'politics' in the question time discussions of the Kenyan Parliament," Int. J. Humanit. Soc. Sci., vol. 1, no. 9, pp. 209-218, 2011.

[8] S. Ide, "Formal forms and discernment: Two neglected aspects of 
universals of linguistic politeness," Multilingua-journal cross-cultural Interlang. Commun., vol. 8, no. 2-3, pp. 223-248, 1989.

[9] G. Elen, “A Critique of Politeness Theories, Manchester: St.” Jerome's Press, 2001.

[10] R. J. Watts, "Taking the pitcher to the 'well': Native speakers' perception of their use of discourse markers in conversation," $J$. Pragmat., vol. 13, no. 2, pp. 203-237, 1989.

[11] Y. Handayani, "Representasi Tindak Tutur Calon Gubernur Sulawesi Selatan: Analisis Wacana Kesopanan Berbahasa," Makara Hubs-Asia, vol. 8, no. 3, 2013.

[12] I. D. P. Wijana, Dasar-dasar pragmatik. Andi Offset, 1996.
[13] N. Hegarty, "Application of the academic motivation scale to graduate school students," J. Hum. Resour. adult Learn., vol. 6, no. 2, p. 48, 2010 .

[14] T. Hayamizu, "Between intrinsic and extrinsic motivation: Examination of reasons for academic study based on the theory of internalization," Jpn. Psychol. Res., vol. 39, no. 2, pp. 98-108, 1997.

[15] F. M. E. Grouzet, N. Otis, and L. G. Pelletier, "Longitudinal crossgender factorial invariance of the Academic Motivation Scale," Struct. Equ. Model., vol. 13, no. 1, pp. 73-98, 2006. 